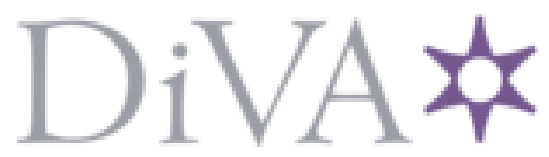

http://www.diva-portal.org

\title{
Preprint
}

This is the submitted version of a paper published in Critical quarterly (Print).

Citation for the original published paper (version of record):

Ullén, M. (2015)

The Situation of the Text: Erotic and Pornographic in Barthes's Camera Lucida.

Critical quarterly (Print), 57(2): 72-89

Access to the published version may require subscription.

N.B. When citing this work, cite the original published paper.

Permanent link to this version:

http://urn.kb.se/resolve?urn=urn:nbn:se:kau:diva-37 165 


\section{The Situation of the Text:}

\section{Erotic and Pornographic in Barthes’s Camera Lucida Magnus Ullén}

Note to reader: this is a pre-print, pre-refereed version of an article published under the same title, but with some alterations, in Critical Quarterly Vol 57, Issue 2, pp. 72-89. For citation, please refer to the printed version.

The distinction between the erotic and the pornographic, for all its vagueness, cuts to the core of the Western intellectual tradition. Much like the more celebrated distinction between high and low art, it is premised on a conception of the aesthetic as incompatible with physical interest. ${ }^{1}$ The notion of the erotic is typically advanced to salvage those explicit representations of graphic sexuality which would seem to meet the criteria for art from the abject trenches of porn. Virginia Woolf, for instance, maintained already in 1929 "that books fall in respect of indecency into two classes;" those "written, published, and sold with the object of causing pleasure or corruption by means of their indecency," and those "whose indecency is not the object of the book but incidental to some other purpose - scientific, social, aesthetic, on the writer's part.” While the police, Woolf held, should be free to suppress the former category (that of “pornography”), the latter "should be left alone. Any man or woman of average intelligence and culture knows the difference between the two kinds of book and has no difficulty in distinguishing one from the other.”2

Other critics have been less confident than Woolf that the distinction can be so easily maintained, and have even been prone to write it off as spurious, the symptom of a fauxbourgeois anxiousness to distance oneself from the very thing one secretly craves - one person's erotica being another one’s pornography, as the saying goes. For how can we tell where the one ends and the other begins? Can one really affirm the utopian potential of an 
erotica which in Gloria Steinem’s words “is about mutuality” and “sexual pleasure,” while still keeping the commodifying threat of pornography at bay? ${ }^{3}$ Recent theorists of the field deny that one can, and declare "the distinction between a 'good' eroticism and a 'bad' pornography” void of interest. ${ }^{4}$

This turn away from questions of evaluation has no doubt been highly productive to the field of porn studies, just as it has to that of cultural studies more broadly. And yet more and more people are starting to feel that despite the undeniable usefulness of this reorientation, something crucial has gone lost in the process. Readings that tease out the cultural significance of more or less sexually graphic texts can often be rewarding enough in their own right. Still, it is difficult not to experience a certain amount of fatigue if not downright boredom when repeatedly confronted with readings which, no matter how sophisticated in theory, in practice amount to little but inventories of the political consciousness of our own particular historical situation: gender, class, ethnicity, etcetera. In reading after reading we are told of the cultural significance of texts of various kinds - verbal, visual, aural - yet only rarely do we hear about the personal significance the text carries for the individual critic. Those bold enough to be explicit about what pornography means for them personally tend not to be academics, or in the rare cases when they are, to admit to liking porn, but not saying much about what they like. ${ }^{5}$

Failing to discuss one's own reaction to the text studied would seem a particularly odd omission when discussing pornography and erotica, for most people would surely agree with Woolf that the distinction makes intuitive sense. "I know it when I see it,” Justice Potter Stewart famously defined pornography, and he was right: the difference between erotica and pornography is one that hits our senses, and does so sharply, just like that equally sharp distinction between the realm of art and the realm of commodities, which has a way of making itself felt for me despite our difficulties of defining it in practice. ${ }^{6}$ It is only when we 
try to distill our experience of this or that text as erotic rather than pornographic (or vice versa) into some general formula which holds true for all texts that the distinction seems to crumble, and we are forced to admit, somewhat shamefacedly, that any attempt to translate our phenomenal experience into a linguistic statement available for all will likely blur the edges of the distinction so drastically as to make it useless in practice if not in theory.

If anyone should be able to help us out of this predicament, then surely it is Roland Barthes, who grappled with the erotic dimensions of reading under the slogan of the jouissance du texte, making clear that it can be an activity as intense as physical orgasm - yet an orgasm without ejaculation, without a fulfilling end. Barthes's thinking on this matter is of special significance because his writings have done so much to promote the wider conception of textuality that lies behind the contemporary textual approach to phenomena such as pornography. It would no doubt be a mistake to equate the generalized sense of textuality which is operable in the humanities and the social sciences today with Barthes's view of the Text as “a methodological field,” yet there can be little doubt that the latter has played a pivotal role in preparing the way for the former. ${ }^{7}$ Barthes's Text is essentially a roll-call for taking a semiotic approach to culture; its productivity to disciplines beyond literary studies derives from the fact that the idea of textuality has the strategic advantage "of cutting across both epistemology and the subject/object antithesis in such a way as to neutralize both, and of focusing the attention of the analyst on her own position as a reader and on her own mental operations as interpretation.”8 Much of Barthes’s later work can be seen as a way of complicating this semiotic approach, in that it tirelessly reminds us of the erotic aspect of the expanded notion of the text that underlies his earlier ideological analyses. Signs, he explained in an interview with Bernard-Henri Lévy, “are only important to me if they seduce or irritate me. Signs in themselves are never enough for me, I must have the desire to read them.”9 Herein lies the unique contribution of Barthes to critical theory: that his unflinching attempt to 
unveil the ideological agenda of cultural discourses never loses sight of the fundamental importance of what is seemingly a wholly subjective sense of the text - of what it means for me.

Given the attention Barthes devotes to this ostensibly subjective sense of the text, it is all the more frustrating that what he explicitly has to say on the distinction between the erotic and the pornographic would seem to echo so closely the standard valorization of the former at the expense of the latter. In La Chambre claire (his remarkable little book on photography, rendered into English as Camera Lucida), for instance, he explicitly separates “the 'heavy' desire of pornography from the 'light' (good) desire of eroticism”, and links the opposition between the pornographic and the erotic to that book's central distinction between studium and punctum, that is, between a photo's cultural significance and its ability to touch the individual viewer. Recently, several critics have offered vital new perspectives on this highly suggestive text and on its central concept of punctum, which seems at once so immediately illuminating and so frustratingly elusive. ${ }^{10}$ While the originality of Barthes's notion of punctum is generally conceded, its theoretical usefulness remains contested. As James Elkins remarks, “The punctum is used to speak about viewer’s responses that are taken to be idiosyncratic, unpredictable, or essentially incommunicable: yet by citing the punctum to theorize such responses, historians and critics make it public and accessible to other readers, which is, I take it, the exact opposite of what Barthes intended.” ${ }^{11}$ Consequently, critics have either tended to use the concept in a reductive fashion, as a mere synonym for personal experience, or have been prone to stress its idiosyncratic nature, as a key to understanding Barthes rather than understanding photography. ${ }^{12}$ Furthermore, while the concept of punctum has been much discussed, its relation to the distinction between the erotic and the pornographic, perhaps because it is carried out as in passing, has been either entirely 
overlooked or dismissed as an inconsequential reiteration of the evaluative distinction of Woolf. $^{13}$

On the face of it, Barthes's comments may indeed seem merely to repeat the traditional valorization of the erotic at the expense of the pornographic. Whereas the erotic image in Barthes's view implicitly refers to "a kind of subtle beyond - as if the image launched desire beyond what it permits us to see,” the pornographic photo, he goes on to say, lacks the distinguishing element of truly engaging photographs: "for me, there is no punctum in the pornographic image.” ${ }^{14}$ Barthes’s binaries, however, are rarely as clear-cut as they first may seem. With less skillful readers, admittedly, distinctions like that of the lisible and the scriptible habitually deteriorate to simply an evaluative distinction, a precious way of distinguishing the good from the bad. In the work of Barthes himself, however, it is clear that the terms are not so much a rigorous distinction between different types of discourse as an acknowledgement of the existence of different modes of reading. The distinction between studium and punctum, as we will see, similarly should be seen less as an attempt to set up a rigorous distinction than as a strategy - in the tradition of Brecht and the Russian formalists for de-automatizing our preconceptions of the phenomenon studied by translating our thoughts about it into a different theoretical vocabulary. Barthes's almost off-hand reference to pornography, I will argue, forms something of a punctum in its own right in Camera Lucida, that is, it can be looked upon as an apparently inconsequential aspect of a larger whole which nevertheless may allow us to rewrite the story told in such a manner that we ourselves - or, rather, our critical activity - can no longer be said to be fully distinct from it. Rather than dismiss Barthes's distinction between the erotic and pornographic on the grounds that it is moralistic, then, I will suggest that we look upon it as emanating not from the text itself, but from the interpretive situation which already involves the reader as well as the text. 
Which brings me to my thesis, namely, that our inability to distinguish between the erotic and the pornographic derives not so much from a flaw in the distinction as such, as from the undertheorized nature of the very concept of textuality that critics have drawn on in the wake of Barthes and others. The concept of the text notably contains an inherent doubleness, which while well-known is all too seldom highlighted: the text designates both a linguistic entity, and our phenomenal experience of this entity. Adding to the confusion, it is far from clear whether it is the linguistic entity or our phenomenal experience of it that must be said to constitute the material aspect of the text - the answer varies from critic to critic, and at times, within the critical practice of individual critics. And yet the root of the confusion is not difficult to grasp: it is made up of the illegitimate (or, if you will, ideologically motivated) separation of the text from its mode of production, that is to say, of our division of what is in fact a continuous interpretive act into a series of discrete objects that we call the Writer, the Text, and the Reader, or, differently put, of the reification of a temporal process into a series of spatial constituents. The dilemma is not unknown, nor is its remedy, especially not to critics who have taken the Marxist lesson of reuniting what has been falsely separated to heart: it consists of replacing the concept of the text with that of situations. Properly considered, Fredric Jameson holds, what literary histories are concerned with is "the history of the situations of the texts, and not some 'history' of the texts themselves [...]."15

My first claim in this essay, then, is that Barthes should be seen as an early practitioner of what Jameson calls metacommentary. What is truly original in Barthes is the way he figures his own interpretive pleasure into the text under study, so that his own text becomes the reflection not only of this or that text, but of the very situation of interpretation. My second claim is that the concept of punctum to remain a productive one must be wrenched away from the field of visuality in which it has become almost a theoretical by-word, much flaunted but rarely understood. If we cease to obsess about what Barthes might have meant by the term and 
concentrate rather on how it is used in Camera Lucida, it can be seen that the concept of punctum is merely contingently linked to photography, and more usefully thought of as a general aspect of what Barthes calls Text. My third claim, finally, is that such a rhetoricohermeneutical approach to the concept of punctum also allows us to argue the continued relevance not only of the much maligned distinction of the erotic and the pornographic, which Barthes briefly revisits in Camera Lucida, but of aesthetic evaluation as such. Once we understand why the distinction between the erotic and the pornographic can not be dismissed as the mere ideological reflex of the critic's own desire, we also will see why the ideological nature of aesthetic value judgments does not make them less indispensible for ideological analysis. $^{16}$

\section{The Story of Punctum}

Camera Lucida begins like a first-person novel: “One day, quite some time ago, I happened on a photograph of Napoleon's youngest brother, Jerome, taken in 1852.”17 Having spent much of his life as a critic getting away from the strictures of narrative, Barthes opens the book with a deliberately Proustian air, which is even more pronounced in the beginning of the second part of the book: "Now, one November evening shortly after my mother's death, I was going through some photographs” (CL, 63) - a sentence which is immediately followed by a quotation from Proust. ${ }^{18}$ Adding to the novelistic flavor of the text, its argument is framed by the story-telling tense of the preterite. Both parts of the book notably begin with a series of sections (1-4, and 25-38, respectively) clearly set in the past tense we have learnt to associate with the narrative mode of fiction. While subsequent sections in both parts revert to the present tense that is more habitually employed in academic texts, the preterite briefly but significantly reappears about two thirds into both parts (sections 17 and 39), as well as at the 
very end, or close to it (24 and 47). From the very start of the book, then, the argument it proposes has already been situated as a story.

But then, Camera Lucida is not only an essay on photography, but also a highly personal work of mourning, in which Barthes presents his "discovery" of the nature of the photograph as a direct consequence of coming across a picture of his (recently deceased) mother as a child in a glassed-in conservatory, a Winter Garden. Barthes’s interest in photography, however, begins at least two decades prior to his writing of Camera Lucida. What originally fascinates Barthes is that photography would seem to be a form of representation peculiar to itself in that a photo does not so much represent reality as simply present it. In contrast to all other forms of representation, photography would seem capable of communicating its content without having to resort to some kind of code: "In order to move from the reality to its photograph it is in no way necessary to divide up this reality into units and to constitute these units as signs, substantially different from the object they communicate; there is no necessity to set up a relay, that is to say a code, between the object and its image."19 Camera Lucida returns to the uniqueness of the photograph at the very outset, yet in rather different terms. The semiotic vocabulary of codes gives way to a description that stresses the particularity of the individual photograph, making evident that what Barthes himself claims to uncover is the essence of the Photograph rather than of Photography. For in his view, it is one of the singular characteristics of photographs that they cannot be generalized: the camera ensures that no matter how the photographer stages the shot, what is primarily conveyed to the viewer is always the event as such.

What the Photograph reproduces to infinity has occurred only once: the Photograph mechanically repeats what could never be repeated existentially. In the Photograph, the event is never transcended for the sake of something else: the 
Photograph always leads the corpus I need back to the body I see; it is the absolute Particular, the sovereign Contingency, matte and somehow stupid, the This (this photograph, and not Photography), in short, what Lacan calls the Tuché, the Occasion, the Encounter, the Real, in its indefatigable expression. ${ }^{20}$

In this formulation, which occurs at the very beginning of the book, we have already the themes that Barthes will go on to explore: the singular nature of the relation between representation and represented in Photography, the realism (in the philosophical sense of the term) of the photo, which entails that there is in every photograph something that escapes the intention of the photographer, and by implication, the encounter with the Real (death).

In order to get at the peculiarity of the photo, Barthes sets about analyzing its various aspects. As to the communicative situation, Barthes distinguishes between the Spectator (viewer of the photo), the Operator (or photographer) and the Spectrum (the referent of the photo). The Spectrum is then further divided into two different versions, depending upon how it relates to, or rather, how it is phenomenologically experienced by, the Spectator. On the one hand, there is Spectrum as studium, the culturally connoted theme of the photo, so to speak, that which the photo is about, that which we find interesting in a photo, without being personally touched by it. Opposed to the studium, and Barthes's real interest in this essay, is the punctum, an element of the photograph - albeit by no means of all photographs, or so it will seem for a moment - that "will break (or punctuate) the studium. This time it is not I who seek it out (as I invest the field of the studium with my sovereign consciousness), it is this element which rises from the scene, shoots out like an arrow, and pierces me. [...] A photograph's punctum is that accident which pricks me (but also bruises me, is poignant to me)” (CL, 27). 
It may be well to note, already at this point, how deftly Barthes manipulates his description to fit his phenomenological experience of these matters. The studium, he says, is what we project into the photograph; the punctum, in contrast, is what shoots out of it by its own accord. This is of course not quite the case. The studium, rather, is what we bring to our reading of the photograph as members of a culture; the punctum, what we bring to it as individual persons, with unique biographical backgrounds. In both cases, what we see comes from us, rather than from the photograph, a circumstance that we will have reason to come back to. ${ }^{21}$ It should be noted, moreover, that while Barthes here talks of punctum as a visual phenomenon, in other places he talks about language in very similar terms: "I am interested in language because it wounds or seduces me”22 - much as he is interested in the photo insofar as it "pierces me” and leaves a "wound" (CL, 26). The line between the photo and the text in Barthes's thinking, then, is hardly a rigid one. ${ }^{23}$

The concept of punctum is considerably complicated over the course of the book in that it turns out that the initial definition of it is merely the first step toward a full understanding of the concept. As mentioned, the book comes in two halves, each of which is divided into twenty four sections. This symmetrical arrangement indicates the chiastic nature of the book's plot: in the first part of the book, Barthes discusses a heterogeneous series of photos which are "striped by a detail (punctum) which attracts or distresses me” (CL, 40); in the second part, he identifies a second, general sense of punctum - time - through a discussion of that very particular picture we have already mentioned, that of his mother as a child. It is crucial to observe, however, that Barthes’s original definition takes the same form as his later expansion of the concept: in both cases, the explication takes the form of a narrative.

This circumstance is too often ignored in critical discussions of the concept. For obvious reasons, critics have been prone to associate punctum with visuality. "The punctum,” Michael Fried typically suggests, "is seen by Barthes but not because it has been shown to him by the 
photographer [...].”24 But the punctum of course is precisely not seen, but perceived. Indeed, contrary to what some of Barthes's formulations may seem to suggest, it is arguably not a visual phenomenon at all. Barthes admittedly sometimes writes as if the punctum were made up of this or that visual detail: his assertion that he was pricked by "the belt worn low by the sister (or daughter)” in James Van der Zee’s picture of a family of American blacks, and in particular by "her strapped pumps" (CL, 43), is one such instance, his distinction between punctum and aberrant gesture another ("for me, the punctum is the other boy's crossed arms" [CL, 51]), his discussion of the possibility to identify punctum retrospectively yet a third ("the real punctum was the necklace she was wearing” [CL, 53]). Yet he is careful to point out that “what I can name cannot really prick me” (CL, 51), making evident that it cannot really be the details named that pricks him. This is so because the punctum is both "the element that rises from the scene and pierces me,” and the wound made by this element; the details enumerated, however, are merely contingently related to this element. In some photos, “a 'detail' attracts me. [...] This 'detail' is the punctum” (CL, 42); "Very often the Punctum is a 'detail,' i.e., a partial object” (CL, 43). As these formulations verify, Barthes does not identify punctum with a detail, but with a "detail" - when he uses the word without citation marks, the details no longer prick him, they "prick” him: “Certain details may 'prick’me” (CL, 47). If we attend to the letter of Barthes's text, then, it is quite clear that the relation between detail and punctum is of a figural order, that it is as if the details were the punctum.

Punctum, then, is not so much this or that detail that draws the viewer's attention, it is, rather, that within the situation of viewing the picture which awakens our very desire to speak of it all. The function of the details is simply to allow the critic to tell a story about that which cannot be named (the punctum). In this respect they are structurally identical to the Winter Garden Photograph in the second part, a point of no small interest in such an elegantly conceived story as that of Camera Lucida. Like the Winter Garden Photograph itself, these 
details are held up as so many objective correlates of a wound - or rather, a relation - that cannot be directly depicted.

Quite understandably, the peculiar circumstances surrounding the Winter Garden Photograph have led a number of critics to look upon it as the punctum of Camera Lucida itself. As Margaret Olin and others have argued, it may well be non-existent, or simply a fictive displacement of a different picture actually shown in the book, La souche. ${ }^{25}$ While this possibility does indeed open up interesting possibilities, following Barthes’s own argument in the book ("the detail which interests me is not, or at least is not strictly, intentional” [CL, 47]) the very likelihood that the photograph has been planted would seem to rule out the suggestion that it forms a punctum; it would seem, rather, an accessory of studium connoting Literarity. The enduring theoretical significance of the book arguably comes out more clearly if we consider instead the implications of its comments on the distinction between the erotic and the pornographic.

\section{The Non-Temporality of Pornography}

In the first part of Camera Lucida, Barthes is quite clear on the essentially private character of the punctum: it is the quality of a photograph that surprises the Spectator - and this of course will vary upon who the Spectator is. Interestingly, Barthes goes on to argue that it is precisely the lack of such an element that accounts for the distinction between the pornographic photograph on the one hand, and the erotic on the other: "for me, there is no punctum in the pornographic image" (CL, 59). In the erotic image, by contrast, the punctum "is a kind of subtle beyond - as if the image launched desire beyond what it permits us to see: not only toward 'the rest' of the nakedness, not only toward the fantasy of a praxis, but toward the absolute excellence of a being, body and soul together.” Whereas "the pornographic body 
shows itself” but “does not give itself," the erotic photograph is marked by an air of generosity: "the photographer has found the right moment, the kairos of desire" (CL, 59). Barthes's recourse to the concept of kairos makes evident that the punctum that the pornographic photo is said to lack is essentially of a temporal nature, that the "being” which Barthes finds inscribed into the erotic photo is a temporal being.

Stressing that the Winter Garden Photograph bears a punctum for him alone, Barthes in the second part of the essay goes on to identify another kind of punctum, not deriving from the detail that breaks out of the picture's studium and as it were draws our attention in spite of the photo's theme, but arising out of the very essence of the Photograph as such: "This new punctum, which is no longer of form but of intensity, is Time, the lacerating emphasis of the noeme ('that-has-been'), its pure representation” (CL, 96). This second form of punctum, then, is not so much of an affective as of a temporal or historical order. In effect, Barthes transposes affectivity - punctum in its singular form, that which makes the photo interesting for me - into history, and he does so by turning his analysis of the essence of the photo into a story. The narrative of Camera Lucida, to recapitulate, moves from a discussion of the photograph as a culturally coded studium broken by a punctum - a concept which in turn is divided into two by the intervention of a story ("Now, one November evening shortly after my mother’s death...”; CL, 63) - to reach at the end "the very letter of Time” (CL, 119).

Through this transposition of the affective into the historical, Barthes turns mundane plaisir into blissful jouissance, in a word, he eroticizes the text. By presenting his theorizing of the photo as a story rather than as science - as literature rather than theory - Barthes produces an allegorical figure of the story told which is crucial for his purpose of conjoining punctum as historical accident, to the more general understanding of punctum as time. That the Winter Garden Photograph itself is never shown in the book is presumably because it could not possibly have the same impact on us, as it has on Barthes. Its disclosure, then, 
would inevitably be something of a let-down, and could at best be construed as the somewhat pornographic gesture of "showing it all." Keeping the picture hidden is thus a way of eroticizing the text, of allowing the reader to imagine the picture without exposing him or her to the naked reality (never as enticing as the veiled figure). The picture thus becomes an analogon for the story as such, an allegory of the very narrative Barthes is telling.

It is not by chance, then, that Camera Lucida has a more distinctively novelistic flavor than any of his other books. In fact, Barthes's claim that the picture of his mother is instrumental in bringing about this insight is really something of a ruse: Barthes was clear on the essentially deictic quality of the photograph several years before his mother died. ${ }^{26}$ But pretending that his thoughts about photography are dependent upon the picture of his deceased mother allows him to do what novelists have always done, namely to move from the particular and individual to the universal by presenting a singular reading of a social phenomenon under the guise of a universally meaningful story. ${ }^{27}$

Barthes's transposition of the affective into the historical thus allows him to read not only individual photographs, but the Photograph as such, and gives him the critical leverage to critique the ideological nature of the studium. For veiled beneath the triviality and sheer mass of photographs in present society, punctum in the general sense Barthes arrives at by telling it as a story, is an ingredient of every photograph: "It is because each photograph always contains this imperious sign of my future death that each one, however attached it seems to be to the excited world of the living, challenges each of us, one by one, outside of any generality (but not outside any transcendence)" (CL, 97; my emphasis). Hidden behind the readerly layer of the studium of the photographic text lies a writerly punctum, an aspect of the text that is not there to be read but which can always be produced by being written.

Or at least, punctum ought to be a component of every photograph. We remember, however, that Barthes has already declared that "there is no punctum in the pornographic 
image.” It is true that this statement refers to a less general form of punctum - but we have also already seen that Barthes distinguishes between the erotic and the pornographic photo on temporal grounds, on account of the former presenting "the right moment, the kairos of desire.” Barthes does not turn back and say that the pornographic photo lacks the general form of punctum as well in so many words; but he does suggest, in conclusion, that pornography is one of the means by which society tames the photograph by invoking the tableaux vivants to be found in “a New York porn shop” (CL, 118). ${ }^{28}$

We have every reason, however, to reverse Barthes’s suggestions about the pornographic photo on one crucial account: we should grant that it may very well be the experience of having been drawn into the photograph by the presence of a punctum in the form of this or that odd detail, of being surprised into desire by some indefinable look in the model's face or posture, that makes people prone to go back to pornography again and again despite knowing full well in advance that they are unlikely to find anything new therein. What pornography lacks - at least, so it seems for me - is not necessarily punctum in the form of such piercing details, but precisely the generalized form of punctum as time. Not that this temporal dimension is not there - as its producers often point out, the principal attraction of pornography is its indexical indubitability, that what is depicted is not sex represented but sex presented. But in pornographic pictures, the intervention of the masturbatory response it is designed to elicit turns the photographic noeme of "that-has-been" into the very different impression of "this-is." The punctum as time is there all right, but it is also immediately consumed, that is, it does not survive the act of reading.

Usually, when we read - and it should be noted that Barthes himself is prone to use the verb "read" rather than "view" in relation to photographs - we ascribe significance to the text: the office of the reader could be said to be that of producing the allegorical meaning of the text - at least, that is the way reading is usually taught in academic disciplines like literary 
studies: “all commentary,” as Northrop Frye aptly remarks, “is allegorical interpretation.”29 But the reader who is moved by pornography - the masturbating reader - takes an interest not in its allegorical but its affective sense - not in what the text means for all, but that the text is there for me. Disregarding the link between pleasure and ideology, this reader need not view the text in terms of desire - that is, in turns of a pleasure always already overdetermined by this or that ideology - but can relate to it in terms of pleasure pure and simple. This is why critical readings of porn so rarely manage to move beyond a simple decoding of the studium of the pornographic text - while the text the academic reads may be precisely the same as the one the masturbating consumer partakes of, the situation of the text differs radically depending upon what kind of reading it is subjected to. In principle, of course, the allegorical potential of pornography is just as great as for any other type of text, and the academic reader will have little difficulty in articulating it. Only, the masturbator does not interpret so much as inhabit the discourse at hand. Such a reader makes no attempt to translate the literal sense into some spiritual signified, but enjoys it as if it formed an alternative, phenomenally selfsufficient, reality, which makes no real attempt to say anything about reality, but is quite content merely to cater to the reader's desire that the world be there for me. Paradoxically, taking such an exclusive interest in the private significance of the text entails that what the text means for me remains unarticulated, as my personal investment in the text cannot be known, even to me, unless it be translated into this or that story - this or that allegorical adumbration - in principle readable for all.

The objective proof of this is readily apparent in that pornography is incompatible with proper storytelling. Steven Marcus makes the point with considerably acuity in The Other Victorians, his classic study of nineteenth-century pornography: "the form of a pornographic work of fiction ... has only an excuse for a beginning, but once having begun it goes on and on and on and ends nowhere; it really has no ending, since one of its cardinal principles of 
existence is repetition.” ${ }^{30}$ Any pornographic film will make apparent that the same holds true today. Or as Slavoj Zizek puts it, “congruence between the filmic narrative (the unfolding of the story), and the immediate display of the sexual act, is structurally impossible: if we choose one, we necessarily lose the other.” ${ }^{31}$ Differently put, the ideological function of pornography lies not with this or that meaning (although, as studium, this meaning is certainly there), but in censoring our very desire to produce an awareness of how my sense of pleasure is related to this meaning, that is, in foreclosing the unfolding of its punctum in the form of a narrative of interest not merely for me for the duration of my excitement, but for all, including, of course, myself after my sexual excitement has abated. In technical terms: pornography censors the allegorical sense of the text, thereby making us blissfully forgetful of how our private enjoyment of the text is related to its ideological underpinnings.

\section{The Situation of the Text}

As the above discussion has shown, in separating a good eroticism from a bad pornography Barthes seemingly retains the conventional evaluative implication of the distinction. I have been at pains to show, however, that Barthes's seemingly offhand treatment of the two terms does not so much buy into this evaluation, as expose its underlying premise, namely that eroticism is considered good because it allows us to tell the story of our own engagement in the work at hand, whereas pornography in contrast denies us this potential for narrative bliss in offering us the prospect of a moment of pleasure to be immediately consumed. The distinction between pornography and erotica, Barthes suggests, is based upon what kind of stories the discourse in question allow us - or force us - to tell.

As we have seen, pornography on Barthes's analysis contains no punctum; that is to say, it forms a story in which there is no temporal distance between the reader (or user) and the tale. This lack of distance between tale and reading is precisely what accounts for the attraction of 
pornography, but also for the revulsion against it. To follow the psychoanalytic drift of Barthes's essay, we could say that the erotic and the pornographic reflect respectively a Symbolic and an Imaginary conception of the subject. Whilst the erotic discourse enforces a distance between the subject and the narrative s/he partakes of, pornography is premised on the imaginary - that is to say, masturbatory - identification of reader/viewer and narrative. Being of an imaginary rather than symbolic order, the letter of the pornographic discourse is suppressed, to the effect that its signified is consumed rather than produced, thus suspending its textual character.

With this, I think we may be said to have arrived at an understanding of what punctum is: it is the manifestation on the level of the individual of what we have come to talk about as the political unconscious. Pinpointing what may first seem a purely subjective reaction to texts, the concept of punctum allows us to account for the mediating role of narrative in dealing with this central if somewhat elusive concept. The element that rises out of the photograph and pricks us with history, regardless of what “detail," if any, it emanates from, links the Spectator to the Spectrum; that the precise nature of that link always remains to be specified as we have seen, it can be told as a story only after having instilled a wound - makes evident that we are dealing with the human temporality of psychoanalysis rather than the divine one of religion. In human temporality, psychoanalytic practice demonstrates, the past remains present because everything that happens to us lives on in our bodies. While our experiences may be more or less violently repressed or simply quietly embedded amongst those things we don’t think about anymore because they seem to us so ordinary as to lack any real significance, they are always liable to make themselves felt again, as is suggested by Proust's madeleine no less than Freud's symptom.

In constituting such a historical wound through its very form (that-has-been), the photograph as analyzed by Barthes ought always to remind us of the presence of death in life, 
and should thus ceaselessly call to mind the material conditions of existence. As the general function of photography is in fact if anything the very opposite of this, we can only conclude that our society has found some way of repressing the link between photography and death. That, at any rate, would seem to be the point at which Camera Lucida arrives: the tableux vivants of the "New York porn shop" he evokes in the book’s last section suggests that pornography and pornographic excitement is a means to such a repression. And yet, as we have seen, Barthes's distinction between the erotic and pornographic is clearly not of an evaluative order: the pornographic image is distinguished from the erotic one not because it is less aesthetically satisfying or morally more distasteful than the latter, but simply because it lacks a temporal dimension the erotic image openly displays. Indeed, the distinction between the erotic and the pornographic in Camera Lucida is no less unstable than that between punctum and studium. Just as punctum begins as an aberrant detail, perceivable only in some photographs, but becomes in the latter half of the book a universal trait of photographs, the function of censoring the punctum which at first is expressly associated only with the pornographic photo, in the final pages of Camera Lucida seems a general feature of photography. The pornographic, in other words, no longer seems a quality of specific texts (pornographic photos); the very situation of consumer society deserves to be labeled pornographic.

Notwithstanding the productiveness of conceding the Textuality of culture, there is, then, a certain incommensurability between contemporary Cultural Studies and the consumer culture often studied, for while the former persists in studying the allegorical sense at the center of ideologies of the Text such as semiotics, the principal ideological feature of the latter would seem to be that it has found an affective mechanism for dispensing with allegory altogether. Pornography, I have argued, is a case in point: it is the immediate mode of reading which pornography habitually - if not exclusively - generates, that is the key to its ideological 
dimension, not the cultural fodder which serves it. The cultural and semantic dimensions of pornography are of course of interest, but what really needs to be understood about pornography is that it sets up an interpretive situation which allows the reader to cancel the allegorical sense of the text by means of the affective space s/he is encouraged to enter.

If this is the case, then people who complain that the textual turn in the humanities threaten to make us blind to the properly aesthetic dimension of art do have a point, if not quite the point they think they have. For what often slides out of view in the attempt to articulate the aesthetic dimension of art in ideological terms is not so much aesthetics as such, as the very aspect of the text we have been concerned with here, that is, what it means for me. In reminding us of this sense, Barthes’s punctum makes plain that aesthetic value judgments cannot simply be dismissed as ideological constructions but should be seen as articulations if often highly unsatisfactory ones - of the ways in which our private histories intersect with that collective universal we call history. Not that aesthetic evaluation per se would make for a better mode of reading texts, but we should recognize that aesthetic evaluation is a means to generalize a sense of what a text or cultural artifact means for me and to claim universal validity for this sense. Critics have certainly been right to point out that there is no such thing as an objective position from which this aesthetic operation may be undertaken - what a text means for me is a subjective sense, and therefore always radically contingent, or differently put, it is always overdetermined by the full range of relations that support the individual's sense of self at any historical moment. But this does not invalidate the desire to transform my sense of what the text means for me into a story of what it could or even should mean for all. On the contrary, to dismiss that desire as ideological (in a negative sense) is in effect to accept as given a critical position from which culture can be studied only as studium, as an allegorical and ideological sense which no longer turns inwards toward our own deepest desires - it is to study culture as a narrative space exempt of utopian possibilities. For an 
important articulation of utopia surely is the hope that my desires may coincide with those of my fellow human beings, the hope that henceforth whatever I do for me will also serve the best interest of all, and that whatever is done for all will also be in the best interest of me.

Rather than reject aesthetic evaluation because of its inescapably ideological nature, then, we should evolve a critical vocabulary that allows us to articulate the principles underlining the operation by which we would have a sense of what the text means for me turn into a sense for all. Reading social and historical phenomena as a text should thus at most be seen as a first preliminary step for cultural criticism. While such a procedure prevents us from succumbing to the illusion of the autonomy of art enforced by the artistic Work, it is liable to make us give in to an ideological assumption of another kind. It is all too easy to assume that because the ideological dimension of the text will always be circumscribed by the historical situation in which it is read, the text itself must also always already be ideological, when in fact it is more accurately described as neutral. Neutrality is something very different from autonomy: it means merely that the text as such will never align itself with any party, but will suffer itself to be used by one and all. The essential question to ask, then, is: How do I translate my sense of what the text means for me into a sense which is valid for all? Until we start asking that question, Barthes understood, we are not performing a critical analysis at all, but remain in the confines of whatever ideology is dictated by the situation of the text. 


\section{Notes}

${ }^{1}$ For the historical roots of this view in the work of eighteenth-century philosophers like Shaftesbury and Kant, see Allison Pease, Modernism, Mass Culture, and the Aesthetics of Obscenity (New York: Cambridge UP, 2000). To this day, pornography for many critics on the left as well as the right embodies "the antiaesthetic;” for the left, see for instance Laura Kipnis, Bound and Gagged: Pornography and the Politics of Fantasy in America (New York: Grove Press, 1996): "Pornography devotes itself to thwarting aesthetic conventions wherever and whenever it can, to disrupting our precious sensibilities at every turn. It's the antiaesthetic” (92); for the right, see Roger Scruton, Beauty (Oxford: Oxford UP, 2009): “Art can be erotic and also beautiful, like a Titial Venus. But it cannot be beautiful and also pornographic [...]” (159). For Stephen Marcus, The Other Victorians: A Study of Sexuality and Pornography in Mid-Nineteenth-Century England (New York: New American Library, 1974 second ed. [1966]), likewise, pornography is “anti-literature, anti-art” (195).

${ }^{2}$ Virginia Woolf, “The ‘Censorship’ of Books,” The Nineteenth Century and After (April 1929): 446-447; cited after Walter Kendrick, The Secret Museum: Pornography in Modern Culture (New York: Viking, 1987), 196.

${ }^{3}$ Gloria Steinem, “Erotica vs. Pornography,” in Outrageous Acts and Everyday Rebellions (London: Jonathan Cape, 1984), 219-230, 227 and 222.

${ }^{4}$ Linda Williams, “Porn Studies: Proliferating Pornographies On/Scene: An Introduction,” in Porn Studies (Durham: Duke UP, 2004), 1-24, 6.

${ }^{5}$ For an example of the latter category, see Alan McKee, "Positive and Negative Effects of Pornography as Attributed by Consumers,” Australian Journal of Communication 34.1 (2007): 87-104; for examples of the former, see Lisa Palac, The Edge of the Bed: How Dirty Pictures Changed My Life (Little, Brown: Boston, 1998), Sallie Tisdale, Talk Dirty To Me: An Intimate Philosophy of Sex (London: Pan Books, 1995). 
${ }^{6}$ For Justice Stewart's ruling, see Jacoblellis v. Ohio, 378 U.S. 184, 197; cited in Linda Williams, Hardcore: Power, Pleasure and the Frenzy of the Visible (Berkeley: University of California Press 1989), 319 n.9. As Frances Ferguson valuably points out in Pornography, the Theory: What Utilitarianism Did to Action (Chicago: University of Chicago Press), Stewart's remark "shifts the burden of his discussion from definitions that would enable us to pick out objects that we have never seen before to the issue of what it means to recognize something less because of what it is than because of what it does in a particular situation” (8).

${ }^{7}$ Roland Barthes, "From Work to Text," in The Rustle of Language, tr. Richard Howard (London: Basil Blackwell, 1986), 56-64, 57.

${ }^{8}$ Fredric Jameson, “The Ideology of the Text.” In The Ideologies of Theory: Essays 19711986. Volume 1 Situations of Theory. London: Routledge, 1988. 17-71, and 191-92, 18. 9 “A quoi sert un intellectual,” Le Nouvel Observateur January 10, 1977; cited in Louis-Jean Calvet, Roland Barthes: A Biography, tr. Sarah Wykes (Oxford: Polity Press, 1994).

${ }^{10} \mathrm{I}$ am thinking particularly of the essays collected in Geoffrey Batchen (ed.), Photography Degree Zero: Reflections on Roland Barthes's Camera Lucida (Cambridge: MIT Press, 2009), especially: Jane Gallop, “The Pleasure of the Phototext,” 47-56; Margaret Iversen, ”What Is a Photograph?” 57- 74; Geoffrey Batchen, “Camera Lucida: Another Little History of Photography,” 259-273. But see also Walter Benn Michaels, “Neoliberal Aesthetics: Fried, Rancière and the Form of the Photograph," Nonsite 1 (January 25, 2011), http://nonsite.org/issues/issue-1/neoliberal-aesthetics-fried-ranciere-and-the-form-of-thephotograph.

${ }^{11}$ James Elkins, "What Do We Want Photography To Be? Response to Michael Fried, 'Barthes’s Punctum',” Critical Inquiry 31.4 (2005): 938-57, rpt. in Batchen (ed.), 171-185, 171.

${ }^{12}$ Particularly helpful in the latter respect are Margaret Olin, ”Touching Photographs: Roland Barthes’s 'Mistaken’ Identification,” rpt. in Batchen (ed.), 75-89, which discusses of the deliberately fictionalizing traits of the book, and stresses the importance of distinguishing 
between Roland Barthes, the author, and Roland Barthes, the character (or "narrator," as she calls him) of Camera Lucida, and Eduardo Cadava and Paolo Cortés-Rocca, ”Notes on Love and Photography,” rpt. in Batchen (ed.), 105-139, which reads the novel as a meditation on love, and goes a long way toward furthering our understanding of how punctum is Barthes's means to bridge the gap between singularity and universality.

${ }^{13}$ Gallop, “The Pleasure of the Phototext," for instance, declares that Barthes "has a strong sense of good and bad in eroticism," and that "he contrasts erotica and pornography to the detriment of the latter" (50).

${ }^{14}$ Roland Barthes, Camera Lucida: Reflections on Photography, tr. Richard Howard (London: Vintage, 2000), 59; henceforth cited in the text as CL. Similar statements can be found in a number of his texts. "The text of pleasure is not necessarily the text that recounts pleasure; the text of bliss is never the text that recounts the kind of bliss afforded literally by an ejaculation,” he typically lets on. "The pleasure of representation is not attached to its object: pornography is not sure. In zoological terms, one could say that the site of textual pleasure is not the relation of mimic and model (imitative relation) but solely that of dupe and mimic (relation of desire, of production.” See The Pleasure of the Text, tr. Richard Miller (New York: Hill and Wang, 1975 [1973]), 55. Williams, "Porn Studies,” writes Barthes off as “yet another example of a cultural critic using pornography as a limit text” (6). I am not saying pornography does not function as such a limit for Barthes, I am merely suggesting that the construction of such limits is of much greater theoretical (and practical) significance than the categorical dismissal of them as "ideological” would seem to suggest.

${ }^{15}$ Fredric Jameson, “Introduction,” in The Ideologies of Theory. Essays 1971-1986. Volume 1 Situations of Theory (Minneapolis: University of Minnisota Press, 1989), xxv-xxix, xxvi.

${ }^{16}$ Late Barthes is in a sense rehabilitating rhetoric as such; if Barthes in early works such as Mythologies, sees the rhetorical tradition as surviving only in the negative form of doxa- 
stereotypes and general opinion - in his later works it is reconceived as the potential fundament of what he speaks about in "L'ancienne rhétorique,” a “dialogue d'amour” a dialogue of love; see Communications 16 (1970): 172-223, reprinted in L'Aventure sémiologique (Paris, Seuil, 1985), 85-164, 93. For a discussion of the relation between the valorization of love in Barthes's later work and ancient rhetorical theory, see Michael Moriarty, “Rhetoric, Doxa, and Experience in Barthes,” French Studies 51.2 (1997): 169-82. 17 “Un jour, il y a bien longtemps, je tombai sur une photographie du dernier frère de Napoléon, Jérôme (1852).” Cited after Roland Barthes, Oeuvres complètes. Tome III 19741980 (Paris: Editions de Seuil, 1995), 1111.

${ }^{18}$ It is commonly observed today that Barthes's notes on the singularity of the photographic noeme takes place under the aegis of fictionality, if not of fiction. For the novelistic quality of the book, see for instance Nancy Shawcross, “Contextualizing Camera Lucida: 'The Third Form,'” in her study Roland Barthes on Photography: The Critical Tradition in Perspective (Gainesville: University Press of Florida, 1997), 67-85; and Margaret Olin, “Touching Photographs," who goes so far as to suggest that Camera Lucida should be viewed as the novel Barthes claimed towards the end of his life that he wanted to write.

${ }^{19}$ Roland Barthes, “The Photographic Message,” in Image - Music - Text, tr. Stephen Heath (New York: Hill and Wang, 1977) [1961], 15-31, 17. Barthes is careful to point out that this view of the photographic image as the "perfect analogon" to reality itself merely shows the “common sense” definition of the photograph, which "has every chance of being mythical” (17). In truth, the photograph does not only denote reality, it connotes a view or attitude towards the depicted content. Like any other sign system, then, the photograph comprises two levels of enunciation, that of denotation and that of connotation. It is unique, not because it alone amongst forms of representation escapes the semiotic realm of textuality, but because 
"here the connoted (or coded) message develops on the basis of a message without a code" (19).

${ }^{20}$ Roland Barthes, Camera Lucida: Reflections on Photography, tr. Richard Howard (New York: Hill and Wang, 1981), 4; hereafter cited in text as CL. For Barthes, Margaret Iversen argues in opposition to Victor Burgin, "the Punctum is emphatically not an occasion for fantasy; rather it is a close encounter with the Real or the lost mother. Lacan understands the Real as a sort of vanishing point which is approached but never grasped, or as Alan Sheridan puts it, 'the umbilical cord of the symbolic.”" See “The Positions of Postmodernism,” Oxford Art Journal 12:1 (1989): 31-34; and Victor Burgin, “Re-reading Camera Lucida,” in The End of Art Theory (London: Macmillan, 1986).

${ }^{21}$ Rune Gade, Staser. Teorier om det fotografiske billedes ontologiske status \& Det pornografiske tableau (Århus: Passepartout, 1997), 226, and Metz agree that the punctum is dependent upon the reader rather than the picture itself; see Christian Metz, "Photography and Fetish,” in Carol Squiers (ed.), The Critical Image: Essays on Contemporary Photography (London: Lawrence \& Wishart, 1991), 161. Gade argues that "In relation to the pornographic photograph, Barthes evidently chooses to fix his gaze at its reality, its overwhelming positivity, its presence. It is therefore disqualified on the grounds of it being too much" (Gade, 226; my translation).

${ }^{22}$ Roland Barthes, The Pleasure of the Text, 38.

${ }^{23}$ In the same text, he suggests that "the word can be erotic on two opposing conditions: if it is extravagantly repeated, or on the contrary, if it is unexpected” (42) - the latter case suggesting the word as punctum. To Barthes, it would appear, the attraction of the neologism is that it forces upon us a sense of the materiality of the word, and it is through this very materiality that we confront rather than evade the world. Furthermore, in The Pleasure of the Text certain forms of language are associated with the "intractability” (45) of reality, 
especially that of the novelist. Cf. Graham Allen, Roland Barthes (London: Routledge, 2003), who likewise notes that "It is not difficult to relate these terms [studium and punctum] to the theory of the text” (126-27).

${ }^{24}$ Fried, “Barthes’s Punctum,” 145.

${ }^{25}$ See Olin, 82; Diana Knight, Barthes and Utopia: Space, Travel, Writing (Oxford: 1997), 265-266; and Batchen, “Camera Lucida,” 261. I agree with Batchen that the point of this argument can not be that the Winter Garden Photo is a fiction, but that it might be - only the latter option is in keeping with Barthes's erotic conception of the text.

${ }^{26}$ The idea occurs already in Empire of Signs, tr. Richard Howard (New York: Hill and Wang, 1982 [1970]) in which the author waxes enthusiast over the blandness of the Haiku, while in The Pleasure of the Text, 45-46, Barthes talks of "intractability" in relation to the essentially denotative aspect of literary realism that he had earlier spoken of in terms of the "The Reality Effect;” see The Rustle of Language, 141-48. See also Calvet, who points out that Barthes's notion that the photograph is intrinsically linked to death likewise preceded the death of his mother by several months.

${ }^{27}$ Barthes admits as much in the book itself: “Once she was dead I no longer had any reason to attune myself to the progress of the superior Life Force (the race, the species). My particularity could never again universalize itself (unless, utopically, by writing, whose project henceforth would become the unique goal of my life)” (CL, 72).

${ }^{28}$ For a discussion of Barthes’s view on erotic desire is influenced by his homosexuality, see Pierre Saint-Amand, “The Secretive Body: Roland Barthes's Gay Erotics,” tr. Charles A. Porter and Noah Guynn, Yale French Studies 90 (1996): 153-71. Saint-Amand ends by stressing the non-teleological character of Barthesian erotics: "We might describe Barthesian sensuality using the terms with which he describes amourous discourse: an expenditure of energy and affection, but one that is 'without end, without crisis'; it is the practice of 'a 
relation without orgasm' (LD [A Lover's Discourse], 73). Barthesian sex (it is perhaps a question of aberration) is always reservatus $(L D, 73)$. There may be another way to say it, thinking this time of the admirable $S / Z$, and say that sex is pensive; it is full of sense but it keeps it in reserve, by not annuling itself in coded satisfaction. It is full of intentions but keeps its secret. It is caught in a voluptuous suspension” (171).

${ }^{29}$ Frye, Anatomy of Criticism, 89.

${ }^{30}$ Marcus, The Other Victorians, 195.

${ }^{31}$ Slavoj Zizek, Looking Awry: An Introduction to Jacques Lacan Through Popular Culture (Cambridge: MIT Press, 1991), 110-111. 